\title{
HIV Antibody
}

National Cancer Institute

\section{Source}

National Cancer Institute. HIV Antibody. NCI Thesaurus. Code C16688.

Produced by B-cells, human immunodeficiency virus (HIV) antibodies reacts with HIV antigens. HIV is a virus which affects white blood cells and eventually destroys the body's natural ability to fight infections. 